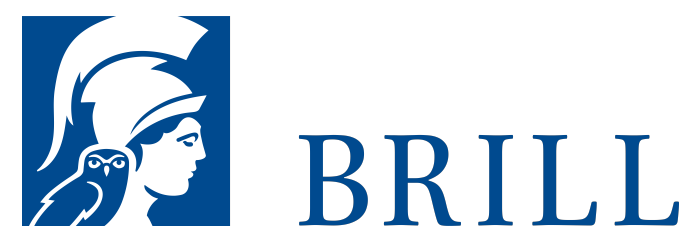

\title{
Latin in Use
}

Amsterdam Studies in the Pragmatics of Latin

Author: Rodie Risselada

Contributions by: A.M. Bolkestein, J.R. de Jong, C.H.M. Kroon, H. Pinkster, R. Risselada

Pages: 126 pp.

Language:

English

Subjects: Greek

\& Latin

Literature,

Classical Studies

Publisher: Brill

Series:

Amsterdam

Studies in

Classical

Philology,

Volume: 8

E-Book (PDF)

Released online:

o1 Oct 2019

ISBN: 978-90-

04-40903-3

List price

USD \$70.00

Hardback

Publication date:

o1 Jan 1998

ISBN: 978-90-

50-63297-3

List price

USD $\$ 66.00$ 
For more information see brill.com

Order information: Order online at brill.com +44330 333 0049 | customerservices@brill.com Submission information: brill.com/authors

Titles published by Brill | Fink, Brill | mentis or Brill | Schöningh: +49(o)715413279216| brill@brocom.de 